University of Nebraska - Lincoln

DigitalCommons@University of Nebraska - Lincoln

USDA National Wildlife Research Center - Staff Publications
U.S. Department of Agriculture: Animal and Plant Health Inspection Service

2009

\title{
Evaluating New Protein Sources for Development of a Deer Repellent Product
}

\author{
Bruce A. Kimball \\ United States Department of Agriculture, National Wildlife Research Center, bruce.kimball@ars.usda.gov \\ Kelly R. Perry \\ USDA-APHIS-Wildlife Services
}

Follow this and additional works at: https://digitalcommons.unl.edu/icwdm_usdanwrc

Part of the Environmental Sciences Commons

Kimball, Bruce A. and Perry, Kelly R., "Evaluating New Protein Sources for Development of a Deer Repellent Product" (2009). USDA National Wildlife Research Center - Staff Publications. 926.

https://digitalcommons.unl.edu/icwdm_usdanwrc/926

This Article is brought to you for free and open access by the U.S. Department of Agriculture: Animal and Plant Health Inspection Service at DigitalCommons@University of Nebraska - Lincoln. It has been accepted for inclusion in USDA National Wildlife Research Center - Staff Publications by an authorized administrator of DigitalCommons@University of Nebraska - Lincoln. 
Short communication

\title{
Evaluating new protein sources for development of a deer repellent product
}

\author{
Bruce A. Kimball $^{\mathrm{a}, \mathrm{b}, *}$, Kelly R. Perry ${ }^{\mathrm{a}}$ \\ ${ }^{a}$ United States Department of Agriculture, Animal and Plant Health Inspection Service, Wildlife Services, National Wildife Research Center, USA \\ ${ }^{\mathrm{b}}$ Monell Chemical Senses Center, 3500 Market Street, Philadelphia, PA 19104, USA
}

\section{A R T I C L E I N F O}

\section{Article history:}

Received 22 May 2008

Received in revised form

10 November 2008

Accepted 11 November 2008

\section{Keywords:}

Browsing

Feather meal

Hydrolysate

Wildlife damage management

\begin{abstract}
A B S T R A C T
Several protein sources were tested as deer repellents with captive deer. Black-tailed deer were offered Western redcedar seedlings treated with corn gluten meal, feather meal, poultry blood, hydrolyzed casein, or a control (latex sticker used for treatment proteins). After 37 days, feather meal and hydrolyzed casein provided equivalent protection against browse damage (only $23 \%$ of seedlings significantly browsed). Poultry blood provided less browse protection (44\% browsed), while browse damage to seedlings treated with corn gluten meal ( $73 \%$ browsed) was not statistically different than the control (100\% browsed). Based on the efficacy of feather meal and its low material cost, this protein hydrolysate should be investigated for use in commercial deer repellent formulations.
\end{abstract}

Published by Elsevier Ltd.

\section{Introduction}

Certain proteins (albumen, casein, and casein hydrolysate) reduce deer browse damage when applied to conifer seedlings (Kimball et al., 2005; Kimball and Nolte, 2006a). Herbivores limit consumption of plants treated topically with proteins and protein hydrolysates because they alter the palatability of the plants (Kimball et al., 2008). Despite the fact that these proteins are routinely used in prepared foods (including infant formulas), nutritional supplements, and cosmetics, they are subject to United States Environmental Protection Agency (USEPA) registration under the Federal Insecticide, Fungicide, and Rodenticide Act (FIFRA) as active ingredients in products intended to minimize wildlife damage to agriculture (e.g. for reducing deer browsing of seedlings in regenerated forests). Accordingly, the potential registration cost of a repellent product must be considered when evaluating active ingredients.

It is desirable to use active ingredients exempt from FIFRA registration requirements ( 40 CFR 152.25, Appendix A) because the registration requirements can be minimal for these minimum risk pesticides. Corn gluten meal is an example of a protein that is exempt from FIFRA registration, but has not been evaluated as a deer repellent. If corn gluten meal significantly reduces deer browse damage, a safe and cheap product could be available for

\footnotetext{
* Corresponding author. United States Department of Agriculture, Wildlife Services, National Wildlife Research Center, 3500 Market Street, Philadelphia, PA 19104, USA. Tel.: +12675194930.

E-mail address: bruce.a.kimball@aphis.usda.gov (B.A. Kimball).
}

immediate and widespread use on non-food plants by virtue of its exempt status.

In lieu of an effective deer repellent from among the minimum use pesticides, a decision to pursue registration of one of the effective proteins (hydrolyzed casein for instance) must be made. Because this decision should consider both efficacy and potential cost, inexpensive proteins should also be evaluated as deer repellents before proceeding with registration. Two examples of cheap and potentially efficacious protein are hydrolyzed feather meal (rendering product) and poultry blood (rendering process waste). In order to make an informed decision about development and registration of a protein-based deer repellent, these alternatives to hydrolyzed casein should be tested by bioassay.

Corn gluten meal, feather meal, and poultry blood were tested along with hydrolyzed casein (a demonstrated repellent protein) and a control in a cafeteria-style bioassay with captive deer at the outdoor facilities of the USDA-APHIS-WS National Wildlife Research Center in Olympia, WA during the period of 23 October to 29 November, 2007. At the outset of the bioassay, we anticipated that poultry blood would reduce deer browsing relative to the control and that feather meal and corn gluten meal would have minor impacts.

\section{Materials and methods}

\subsection{Test substances}

Corn gluten meal (CGM) was purchased from Planet Natural (Bozeman, MT, USA) and hydrolyzed casein (HC) was purchased from American Casein Co. (HCA-411; Burlington, NJ, USA). Poultry 
blood (PB) and feather meal (FM) were obtained from a commercial poultry rendering facility. A latex sticker solution consisting of $5 \mathrm{~mL}$ Tactic $^{\circledR}$ (Loveland Industries, Greeley, CO, USA) per liter tap water was used to adhere the test proteins to the plants and served as the negative control (CON). The latex sticker was added to the liquid PB at the same concentration.

\subsection{Treatments}

Test substances were applied to western redcedar (Thuja plicata) bare-root seedlings (ca. $30 \mathrm{~cm}$ tall) transplanted in 0.2 ha outdoor pens. Treatment plots consisted of twelve seedlings in $3 \times 4$ arrangements with $1 \mathrm{~m}$ spacing between trees. All five treatments (CGM, HC, PB, FM, and CON) were replicated in five pens. Within pens, the plots were separated from each other by at least $3 \mathrm{~m}$. Powder treatments (CGM, FM, HC) were applied by spraying the seedlings with the latex sticker solution using a tank-type garden sprayer and dusting with the powder by hand. Seedlings in control plots were sprayed with the sticker solution only, while the poultry blood solution (containing the sticker) was applied by spray from a tank-type garden sprayer.

\subsection{Subjects}

Two adult female and one adult male black-tailed deer (Odocoileus hemionus columbianus) were herded into each test pen. During the bioassay, subjects had ad libitum access to a pelleted basal diet, water, mineral block, and shelter. Browsed seedlings were not replaced during the course of the bioassay which lasted 37 days.

\subsection{Responses}

The number of bites observed on each tree were recorded on days $1-5,7,10,14,19,24,28,33$, and 37 or until the tree sustained a total of 10 bites (according to the method of Kimball et al., 2005).

\subsection{Statistical analyses}

A Kaplan-Meier survival analysis was performed on the data to compare survivability distribution functions among treatments using the Wilcoxon test of equality (PROC LIFETEST; SAS, Cary, NC, USA). "Failure" was defined as the first experimental day when 10 bites were observed on the individual tree. Trees that survived to the end of the experiment (did not meet definition of failure) were assigned an arbitrary failure day of 50 and censored according to the procedures of survival analysis. Cumulative bite data at the end of the experiment (day 37) were rank-transformed by treatment ( $1=$ fewest bites; $5=$ most bites) and a Kruskal-Wallis test was performed with treatment and test pen as fixed effects and rank the response (Iman, 1982).

\section{Results and discussion}

A single data sheet from one of the test pens was permanently displaced after termination of the experiment. Therefore, no data from this pen were included in the analyses. Moreover, the results and conclusions of the experiment were unchanged by addition of the partial data from the pen in question. Wilcoxon test of equality among treatments was highly significant $(P<0.0001)$, indicating that survival distributions varied among the treatments (Fig. 1). Analysis of the rank data indicated a significant treatment effect $(P<0.0001)$ while accounting for differences among the test pens $(P=0.011)$. Kruskal-Wallis analysis further indicated that redcedar treated with CGM did not survive deer browsing any more than control seedlings. Although PB prevented browse damage

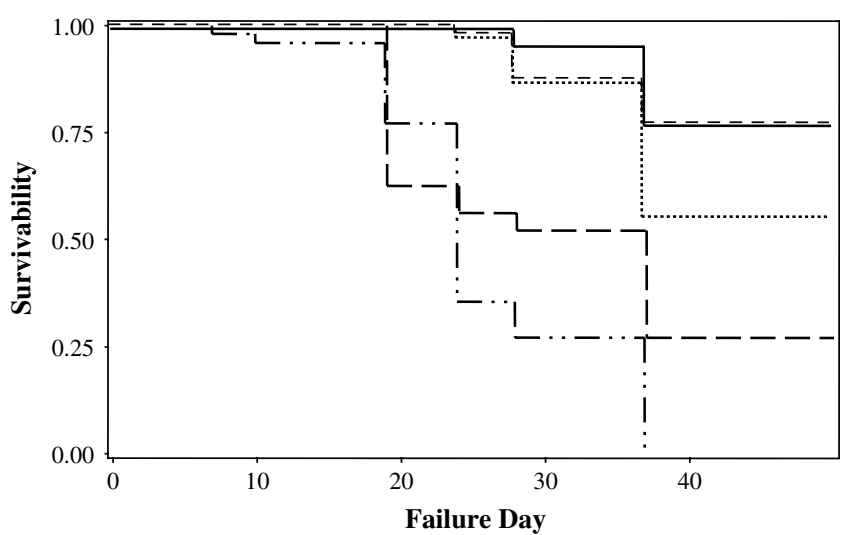

Fig. 1. Survivability functions of western redcedar (Thuja plicata) seedlings treated with protein or control. Captive black-tailed deer (Odocoileus hemionus) had access to treatment plots for 37 days in four replicate pens. Failure of an individual seedling was indicated by sustaining 10 or more bites. - , hydrolyzed casein; - - - -, feather meal; ......, poultry blood; - - -, corn gluten meal; — . . - control.

more than CGM or the control, the most effective treatments were FM and $\mathrm{HC}$ which equally reduced deer browsing of the seedlings.

Contrary to our a priori hypotheses, PB was not highly effective in reducing deer browse damage over the course of the experiment. Inspection of survival distributions indicates that extensive browsing of seedlings treated with PB began about the same time as the controls on day 19 (Fig. 1). One interpretation of this observation could be that PB is actually an effective repellent but the latex sticker failed to keep it adhered to the plant foliage for the duration of the study. However, minimal browsing of seedlings treated with HC and FM until after day 28 suggests that the latex sticker performed adequately for at least four weeks.

Although using waste products (such as PB) in deer repellent formulations would be advantageous because they are inexpensive, in this case the highly offensive odor of PB to humans would likely have limited its use anyhow. The volatile sulfur compounds (rotten egg odors) and short-chain aldehydes (rancid odors) produced by protein and lipid fermentation that were pervasive in each test pen at the time of PB application would not be welcome on landscape surrounding private homes, public parks, etc. Results of this bioassay support earlier contentions that the mere presence of sulfur odors is not the basis of repellency (Kimball and Nolte, 2006b). Despite the volatile sulfur compounds, poultry blood was a poor repellent because it lacked the proteins or peptides found in FM and HC that are necessary to impact seedling palatability.

At the same time, avoidance of unfamiliar stimuli such as odors (i.e. neophobia) is a common strategy employed by herbivores to avoid potential toxicosis (Launchbaugh and Provenza, 1994). Neophobia is the likely mechanism responsible for anecdotal reports of human hair, urine, bars of soap, etc. successfully being used to deter deer browsing. However, avoidance behavior is rapidly attenuated in the absence of alternatives (Kimball et al., 2002) or when exposure to the novel stimuli is not accompanied by a negative consequence (Nolte, 1999). Therefore, the effectiveness of repellents relying solely on odor to deter deer browsing is strongly influenced by availability of other forage options. When foraging options abound, innocuous items may shift resource use. When alternatives are reduced, repellent devices that rely solely on neophobia are unlikely to significantly deter deer browsing.

Multiple studies have demonstrated the efficacy of HC to reduce browse damage to conifers by deer (Kimball et al., 2005; Kimball and Nolte, 2006a,b). However, this is the first demonstration that 
FM can likewise protect seedlings when applied topically. Treatment with FM was much more efficacious for reducing deer browsing of redcedar seedlings than anticipated. After 37 days, only 23 percent of seedlings treated with either HC or FM had been significantly browsed under bioassay conditions that could best be described as "intense browse pressure." That is, unlike free-ranging deer in a forest (reforested unit) or suburban environment (home garden), the subjects in this study had access to no other natural tree or shrubs other than the test trees.

Neither HC nor FM is exempt from USEPA registration requirements under FIFRA. Therefore, any decision to produce a commercially available repellent product using one of these protein hydrolysates as the active ingredient must consider efficacy, suitability of the material for formulation, as well as costs of registration data development and product manufacturing (among other marketing considerations).

While equally effective as deer repellents, these powdered hydrolysates differ most in cost of the raw material. Hydrolyzed casein is a specialty product derived from intact casein, which is principally imported into the United States from New Zealand. As a result, the unit cost of $\mathrm{HC}$ is at least 20 times more than FM, which is produced domestically as part of the poultry rendering process. Both FM and HC are largely insoluble in water, although HC has limited solubility. Hydrolyzed casein resembles a dry flowable powder while FM has an irregular consistency. Ultimately, both may be more suitable for dry formulations.

When evaluating protein hydrolysates for inclusion in deer repellent formulations as the active ingredients, feather meal (FM) should be given strong consideration based on its efficacy and low starting material cost.

\section{Acknowledgements}

Mention of specific products does not constitute endorsement by the United States Department of Agriculture. Technical assistance was provided by Barry Griffith (Technical Chairman, Poultry Protein and Fat Council, US Poultry \& Egg Association). The authors also thank Dr. Jerry Hurley and Mr. John Eisemann for helpful comments on earlier drafts of the manuscript.

\section{References}

Code of Federal Regulations. Title 40: protection of environment. Part 152: pesticide registration and classification procedures.

Iman, R.L., 1982. Some aspects of the rank transform in analysis of variance problems. In: Proceedings of the Seventh Annual SAS Users Group International SAS, Cary, NC, pp. 676-680.

Kimball, B.A., Nolte, D.L., 2006a. Development of a new deer repellent for the protection of forest resources. West. J. Appl. Forest. 21, 108-111.

Kimball, B.A., Nolte, D.L., 2006b. Animal tissue-based herbivore repellents: scary odours or altered palatability? Adv. Vertebr. Pest Manage., 59-72.

Kimball, B.A., Nolte, D.L., Perry, K.B., 2005. Hydrolyzed casein reduces browsing of trees and shrubs by white-tailed deer. HortScience 40, 1810-1814.

Kimball, B.A., Provenza, F.D., Burritt, E.A., 2002. Importance of alternative foods on the persistence of flavor aversions: implications for applied flavor avoidance learning. Appl. Anim. Behav. Sci. 76, 249-258.

Kimball, B.A., Russell, J.H., DeGraan, J.P., Perry, K.R., 2008. Screening hydrolyzed casein as a deer repellent for reforestation applications. West. J. Appl. Forest. 23 172-176.

Launchbaugh, K.L., Provenza, F.D., 1994. The effect of flavor concentration and toxin dose on the formation and generalization of flavor aversions in lambs. J. Anim. Sci. 72, 10-13.

Nolte, D.L., 1999. Behavioral approaches for limiting depredation by wild ungulates. In: Launchbaugh, K.L., Sanders, D., Mosely, J.C. (Eds.), Grazing Behavior of Livestock and Wildlife. University of Idaho, Moscow, Idaho, pp. 60-69. 